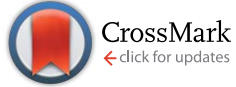

Cite this: RSC Adv., 2017, 7, 8550

Received 28th December 2016 Accepted 20th January 2017

DOI: 10.1039/c6ra28787e

rsc.li/rsc-advances

\section{Synthesis and antioxidant activity of 1,3,4- oxadiazoles and their diacylhydrazine precursors derived from phenolic acids $\uparrow$}

\author{
Nevena Mihailović, ${ }^{a}$ Violeta Marković, ${ }^{a}$ Ivana Z. Matić, ${ }^{\mathrm{b}}$ Nemanja S. Stanisavljević, ${ }^{\mathrm{c}}$ \\ Živko S. Jovanović, ${ }^{c}$ Snežana Trifunovićd and Ljubinka Joksović ${ }^{\star a}$
}

\begin{abstract}
Eight 1,3,4-oxadiazole derivatives containing phenolic acid moieties (7a-h) and eight of their diacylhydrazine precursors $(6 a-h)$ were synthesized, characterized using spectroscopic methods and examined by scavenging of stable DPPH (2,2-diphenyl-1-picrylhydrazyl) radicals. The most potent phenolic 1,3,4-oxadiazoles showed better DPPH scavenging activity in comparison with their corresponding diacylhydrazine precursors as a result of participation of both aromatic rings and a 1,3,4-oxadiazole moiety in resonance stabilization of the formed phenoxyl radical. Four diacylhydrazines $(6 \mathrm{~d}, 6 \mathrm{e}, 6 \mathrm{~g}$, and $6 \mathrm{~h}$ ) and four 1,3,4-oxadiazoles (7d, 7e, $7 \mathrm{~g}$ and $7 \mathrm{~h}$ ) with the best DPPH scavenging activity, were chosen for further evaluation of their antioxidant potential through various assays. The investigated compounds exerted pronounced ABTS radical scavenging capacity, moderate to good $\mathrm{H}_{2} \mathrm{O}_{2}$ scavenging properties and strong ferric ion reducing capacity. Further in vitro evaluation of the antioxidant properties of the most active compounds demonstrated their protective effects in normal lung fibroblasts MRC-5 against hydrogen peroxide induced oxidative stress. Diacylhydrazine $6 \mathrm{~h}$ increased two times the activity of glutathione peroxidase in treated cells in comparison with a control sample and did not affect the superoxide dismutase activity.
\end{abstract}

\section{Introduction}

Reactive oxygen species (ROS) in the form of free radicals (superoxide, singlet oxygen, hydroxyl radical) and neutral molecules (hydrogen peroxide) induce damage of biological macromolecules under oxidative stress and contribute to the pathogenesis of many health problems such as cancer, inflammation, atherosclerosis, cardiovascular and neurodegenerative diseases. ${ }^{1-3}$ The antioxidants prevent the oxidation of biological substrates, lowering oxidative stress, DNA mutations, malignant changes and thus, block the loss of cell function. ${ }^{4}$

Owing to the possibility of facile hydrogen atom transfer and resonance stabilization of the resulting phenoxyl radical, phenolic acids act as chain-breaking antioxidants able to scavenge free radical species. ${ }^{5}$ Natural and synthetic phenolic acids often contain both hydroxyl and methoxy substituents and the positioning of $\mathrm{OH}$ groups is crucial for their antioxidant

${ }^{a}$ Faculty of Science, Department of Chemistry, University of Kragujevac, R. Domanovica 12, 34000 Kragujevac, Serbia. E-mail: ljubinka@kg.ac.rs

${ }^{b}$ Institute of Oncology and Radiology of Serbia, Pasterova 14, 11000 Belgrade, Serbia 'Institute of Molecular Genetics and Genetic Engineering, University of Belgrade, Vojvode Stepe 444a, 11000 Belgrade, Serbia

${ }^{d}$ Faculty of Chemistry, University of Belgrade, Studentski trg 12-16, 11000 Belgrade, Serbia

$\dagger$ Electronic supplementary information (ESI) available. See DOI: $10.1039 / \mathrm{c} 6 \mathrm{ra} 28787 \mathrm{e}$ properties. $^{6-8}$ The combination of the known phenolic antioxidants with heterocyclic pharmacophores in the same unit can be an interesting approach to discover novel more potent radical scavengers as a result of their synergistic effects. Furthermore, one of such heterocycles, substituted 1,3,4-oxadiazole scaffold has been reported to exhibit a broad spectrum of biological activity. ${ }^{9-12}$ Literature searches reveal that 2,5disubstituted 1,3,4-oxadiazole derivatives commonly obtained from diacylhydrazines show antioxidant potential. This class of compounds includes sulfonamidomethane linked 1,3,4-oxadiazoles, ${ }^{13}$ substituted bis(1,3,4-oxadiazoles), ${ }^{14}$ 1,3,4-oxadiazoles possessing benzoxazole, ${ }^{15}$ 1,3,4-oxadiazole tagged thieno $[2,3-d]$ pyrimidines ${ }^{16} \quad$ 2-benzoylamino-5-hetaryl-1,3,4-oxadiazoles, ${ }^{17}$ and 1,3,4-oxadiazoles containing 3-fluoro-4methoxyphenyl moiety. ${ }^{18}$ To the best of our knowledge, there is no available data regarding antioxidant activity of hydroxysubstituted dibenzoylhydrazines in the literature. In this study, a series of 1,3,4-oxadiazoles and their diacylhydrazine precursors derived from phenolic acids was synthesized and screened for radical scavenging properties using several assays.

\section{Results and discussion}

\subsection{Chemistry}

The synthesis of 1,3,4-oxadiazoles from 1,2-diacylhydrazines requires various cyclodehydration agents such as $\mathrm{SOCl}_{2}{ }^{19}$ $\mathrm{POCl}_{3},{ }^{20,21}$ Burgess reagent, ${ }^{22}$ and 2-chloro-1,3- 


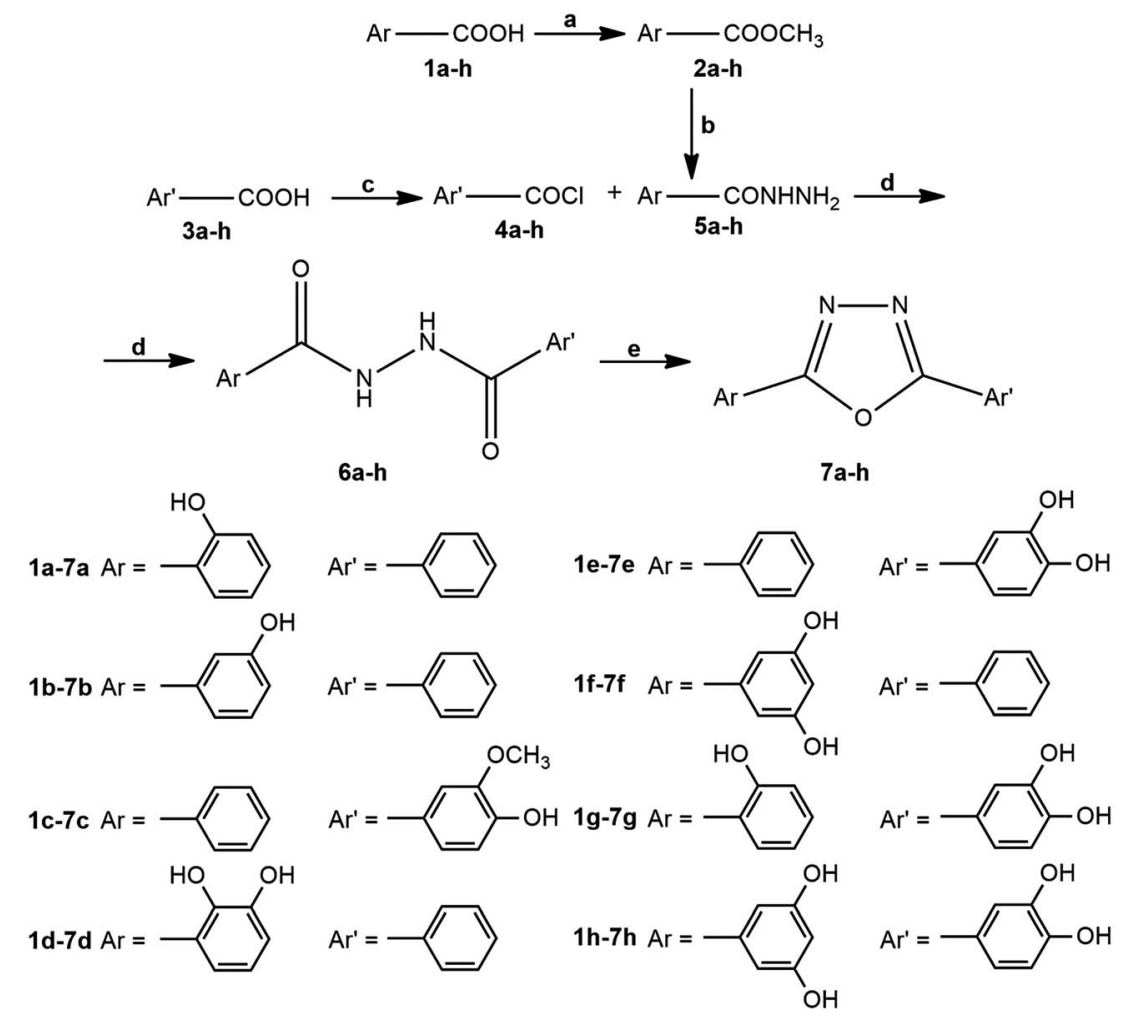

Scheme 1 Reagents and conditions: (a) $\mathrm{H}_{2} \mathrm{SO}_{4}, \mathrm{MeOH}, 5$ h, reflux; (b) $\mathrm{N}_{2} \mathrm{H}_{4} \times \mathrm{H}_{2} \mathrm{O}$, EtOH, 12 h, reflux; (c) SOCl$, \mathrm{DMF}^{\mathrm{C}} \mathrm{CH}_{2} \mathrm{Cl}_{2}, 2 \mathrm{~h}, \mathrm{r}$.t.; (d) THF, 6 h, r.t.; (e) $\mathrm{SOCl}_{2}, 6$ h, reflux.

dimethylimidazolinium chloride. ${ }^{23}$ A series of 2,5-disubstituted 1,3,4-oxadiazole antioxidants incorporating phenol moiety was prepared by reacting aryl hydrazides with substituted 4hydroxybenzoic acids in the presence of phosphorus oxychloride.$^{20}$ Nieddu et al. performed a synthesis of cytotoxic unsymmetrical 1,3,4-oxadiazoles also using $\mathrm{POCl}_{3}$ as cyclodehydration agent. ${ }^{21}$ For cyclization of our 1,2-diacylhydrazines containing more phenolic hydroxyl groups, thionyl chloride was the best choice, and for this purpose, we modified literature procedure for the synthesis 1,3,4-oxadiazoles containing adamantane ring ${ }^{19}$ replacing solvent and excluding base during the preparation of 1,2-diacylhydrazines as well as excluding toluene in the next cyclization step.

The synthetic pathway for the targeted 1,3,4-oxadiazole derivatives $\mathbf{7 a - h}$ is presented in Scheme 1 . In the first step, commercially available aromatic acids $\mathbf{1 a}-\mathbf{h}$ were converted into corresponding methyl esters $2 \mathbf{2}-\mathbf{h}$ in the presence of $\mathrm{H}_{2} \mathrm{SO}_{4} \cdot{ }^{24}$ The obtained esters were then reacted with excess of hydrazine hydrate yielding acylhydrazines $(\mathbf{5 a}-\mathbf{h}) \cdot{ }^{25}$ In order to dissolve polar impurities after the evaporation of the solvent, small amount of water was added to the crude residue and the formed suspension was filtrated and dried. On the other side, commercially available aromatic acids $\mathbf{3 a - h}$ were transformed into acid chlorides $\mathbf{4 a - h}$ in the reaction with thionyl chloride in the presence of catalytic amounts of $\mathrm{N}, \mathrm{N}$-dimethylformamide, according to slightly modified procedure. ${ }^{26}$ The next step was performed immediately due to the low stability of the formed acid chlorides. The obtained acylhydrazine (5a-h) and corresponding acid chloride (4a-h) were stirred at room temperature in dry THF, giving the corresponding diacylhydrazines ${ }^{19}(\mathbf{6 a}-\mathbf{h})$ with satisfactory purity without a need for further purification. It was possible to combine here the condensation of acid chloride ArCOCl with acylhydrazine $\mathrm{Ar}^{\prime} \mathrm{CONHNH}_{2}$ or acid chloride $\mathrm{Ar}^{\prime} \mathrm{COCl}$ with acylhydrazine $\mathrm{ArCONHNH}_{2}$. The selection of precursors for this type of reaction only depends on higher purity and better yields of diacylhydrazines $\mathbf{6 a}-\mathbf{h}$. Finally, diacylhydrazines $\mathbf{6 a}-\mathbf{h}$ were cyclised to 1,3,4-oxadiazole derivatives $\mathbf{7 a - h}$ by treatment with $\mathrm{SOCl}_{2}$ in the reflux conditions. ${ }^{19}$

The exact structure of synthesized compounds $(\mathbf{6 a}-\mathbf{h}$ and $7 \mathbf{a}-\mathbf{h})$ was confirmed by means of ${ }^{1} \mathrm{H}$ and ${ }^{13} \mathrm{C}$ NMR spectroscopy (see ESI, Fig. S1-S32†). All aromatic protons for both classes of compounds displayed signals in the characteristic region ranging from 6.3 to $8.3 \mathrm{ppm}$. Signals present at the lower field in ${ }^{1} \mathrm{H}$ NMR spectra of compounds $\mathbf{6 a}-\mathbf{h}$ correspond to $\mathrm{OH}$ and $\mathrm{NH}$ protons. Their acidic nature was proven by the addition of two drops of $\mathrm{D}_{2} \mathrm{O}$ to NMR sample, which resulted in the disappearance of the corresponding signals as a consequence of fast deuterium exchange. In ${ }^{1} \mathrm{H}$ NMR spectra of $\mathbf{7 a - h}$, due to the cyclization to $1,3,4$-oxadiazole derivatives, signals attributed to $\mathrm{NH}$ protons disappeared and remained only $\mathrm{D}_{2} \mathrm{O}$ exchangeable signals assigned to phenolic $\mathrm{OH}$ protons at the highest chemical shift values.

\subsection{DPPH scavenging activity of diacylhydrazines and their corresponding 1,3,4-oxadiazoles}

The results of DPPH radical scavenging activity of the synthesized diacylhydrazines and corresponding 1,3,4-oxadiazoles, 
Table 1 DPPH scavenging activity of diacylhydrazines and their corresponding 1,3,4-oxadiazoles ${ }^{a}$

\begin{tabular}{|c|c|c|c|}
\hline \multicolumn{2}{|c|}{ Diacylhydrazines } & \multicolumn{2}{|c|}{ 1,3,4-Oxadiazoles } \\
\hline Compound & $\mathrm{IC}_{50}(\mu \mathrm{M}) \pm \mathrm{SD}$ & Compound & $\mathrm{IC}_{50}(\mu \mathrm{M}) \pm \mathrm{SD}$ \\
\hline $6 a$ & $>1000$ & $7 \mathbf{a}$ & $>1000$ \\
\hline $6 \mathbf{b}$ & $>1000$ & $7 \mathbf{b}$ & $>1000$ \\
\hline $6 c$ & $>1000$ & $7 \mathrm{c}$ & $>1000$ \\
\hline 6d & $16.06 \pm 0.40$ & $7 d$ & $14.63 \pm 0.34$ \\
\hline $6 e$ & $20.97 \pm 0.47$ & $7 e$ & $13.59 \pm 0.30$ \\
\hline $6 f$ & $>1000$ & $7 f$ & $>1000$ \\
\hline $6 \mathrm{~g}$ & $17.28 \pm 0.41$ & $7 \mathrm{~g}$ & $15.81 \pm 0.38$ \\
\hline $6 h$ & $22.17 \pm 0.53$ & $7 \mathbf{h}$ & $14.93 \pm 0.36$ \\
\hline
\end{tabular}

Referent antioxidants

Ascorbic acid

$38.78 \pm 0.60$ NDGA

$20.83 \pm 0.23$

${ }^{a}$ Results are mean values \pm SD from three measurements.

expressed as concentration of tested compound that reduce $50 \%\left(\mathrm{IC}_{50}\right)$ of the DPPH radicals are presented in Table 1. From all tested compounds, four diacylhydrazines and four 1,3,4oxadiazoles showed good antioxidant activity, with $\mathrm{IC}_{50}$ values in the range of 13.59 to $22.17 \mu \mathrm{M}$, while $\mathrm{IC}_{50}$ values of ascorbic acid and nordihydroguaiaretic acid (NDGA) were 38.78 and $20.83 \mu \mathrm{M}$, respectively.

Compared to the corresponding 1,3,4-oxadiazoles (7a-h), their diacylhydrazine precursors derived from phenolic acids $(\mathbf{6 a}-\mathbf{h})$ have shown up to $50 \%$ weaker antioxidant activity (Table
1). In these compounds the formation of radicals is possible through heterolytic $\mathrm{OH}$ and $\mathrm{NH}$ cleavage, as it was previously demonstrated by DFT calculations for triazole derivatives. ${ }^{6}$ The radical species formed from derivatives $\mathbf{6} \mathbf{a}-\mathbf{h}$ after the cleavage of $\mathrm{NH}$ bond have no ability for resonance stabilization through the corresponding aromatic ring. Therefore, their role in the antioxidant activity of parent compounds is not significant. On the other hand, in the case of heterolytic OH-cleavage, the unpaired electron of the formed radical can be delocalized across the benzene ring (Scheme 2A), causing an easy formation of phenoxyl radical with lower reactivity and higher stability.

The phenoxyl radical formed from the corresponding 1,3,4oxadiazole derivative (7a-h) can be highly stabilized through resonance since the unpaired electron may be delocalized across both aromatic rings and 1,3,4-oxadiazole part of the molecule (Scheme 2B). All of the compounds which show excellent antioxidant activity (7d, $\mathbf{7 e}, \mathbf{7} \mathbf{g}$ and $\mathbf{7 h}$ ) contain in their structure two neighboring hydroxyl groups having the possibility to form an intramolecular hydrogen bond (Scheme 2B). The most active compound 7e possesses two hydroxyl groups in $m$ - and $p$-positions of the aromatic ring. Substitution of the $m$ hydroxyl group with methoxy one (7c) leads to the loss of the activity due to the less effective radical stabilization by intramolecular hydrogen bonding. Comparing the activity of compound $7 \mathbf{e}$ with the activities of $7 \mathbf{g}$ and $7 \mathbf{h}$ it can be concluded that the presence of additional hydroxyl groups induces a slight decrease of activity. The presence of one or two $\mathrm{OH}$ groups at the second benzene ring in $\mathbf{7 g}$ and $\mathbf{7 h}$ does not contribute to resonance stabilization of radical due to the negative inductive effect of the hydroxyl group. Compound $7 \mathbf{f}$ exerts no antioxidant activity, as it was expected for the

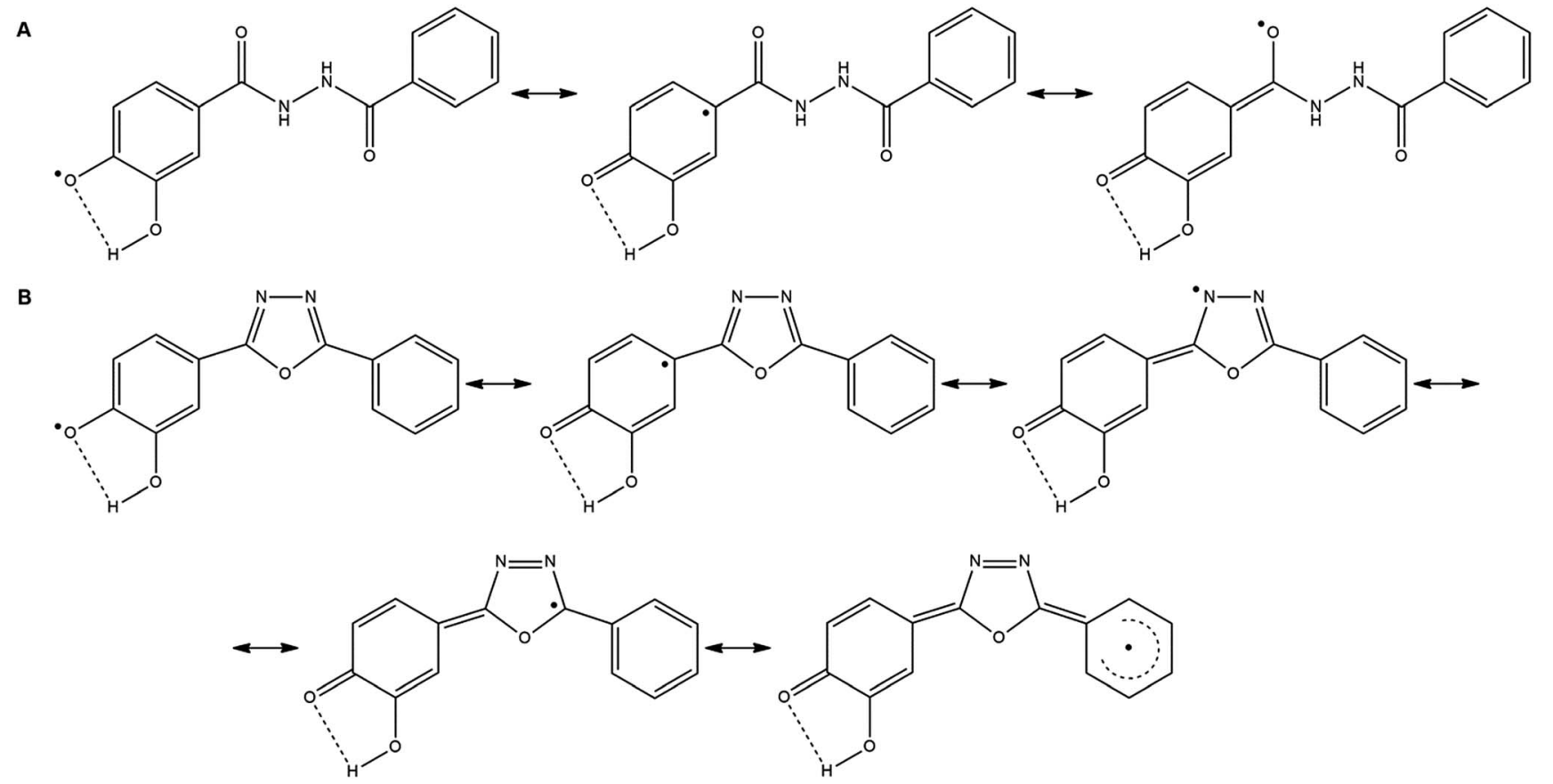

Scheme 2 Resonance stabilization of radicals formed from compound $6 \mathrm{e}(\mathrm{A})$, and $7 \mathrm{e}(\mathrm{B})$, after heterolytic cleavage of $\mathrm{OH}$ bond, and loss of one electron 
Table 2 Antioxidant activities of selected diacylhydrazines and 1,3,4-oxadiazoles

\begin{tabular}{|c|c|c|c|c|}
\hline Compounds & $\begin{array}{l}\text { FC reducing capacity } \\
\text { assay (gGAE per g) }\end{array}$ & $\begin{array}{l}\text { Ferric ion reducing }{ }^{a} \text { capacity } \\
\text { assay }\left(A_{700 \mathrm{~nm}}\right)\end{array}$ & ABTS assay $\mathrm{IC}_{50}(\mu \mathrm{M})$ & $\begin{array}{l}\mathrm{H}_{2} \mathrm{O}_{2} \text { scavenging } \\
\text { assay } \mathrm{IC}_{50}(\mu \mathrm{M})\end{array}$ \\
\hline 6d & $1.141 \pm 0.013$ & $0.296 \pm 0.009$ & $120.1 \pm 5.7$ & $37.41 \pm 0.89$ \\
\hline $6 g$ & $1.107 \pm 0.003$ & $0.461 \pm 0.008$ & $133.3 \pm 35.7$ & $43.92 \pm 0.38$ \\
\hline $6 h$ & $1.470 \pm 0.019$ & $0.478 \pm 0.009$ & $102.6 \pm 7.5$ & $57.00 \pm 1.43$ \\
\hline $7 d$ & $0.918 \pm 0.008$ & $0.270 \pm 0.005$ & $118.4 \pm 31.2$ & $100.33 \pm 5.89$ \\
\hline $7 \mathrm{~h}$ & $1.209 \pm 0.006$ & $0.426 \pm 0.004$ & $120.6 \pm 18.5$ & $75.17 \pm 5.23$ \\
\hline Ascorbic acid & - & $0.173 \pm 0.007$ & $242.6 \pm 7.3$ & $22.40 \pm 0.60$ \\
\hline
\end{tabular}

molecule which contains two $m$-hydroxyl groups in its structure and it does not allow extended resonance stabilization.

\subsection{ABTS, $\mathrm{H}_{2} \mathrm{O}_{2}$ scavenging activity and reducing capacity}

The compounds which showed the best DPPH radical scavenger activities $6 \mathbf{d}, 6 \mathbf{6}, \mathbf{6 g}, \mathbf{6 h}, 7 \mathbf{d}, 7 \mathrm{e}, 7 \mathrm{~g}$ and $7 \mathrm{~h}$ have been chosen for further examination of their in vitro antioxidant properties through ABTS radical scavenging, peroxide scavenging assays and reducing capacity. The obtained results are summarized in Table 2.

Radical scavenging capacity of synthesized compounds was tested using ABTS radical cation scavenging assay, which is another widely used method for the estimation of in vitro antioxidant ability. The obtained results (Table 2) showed that all tested compounds possessed more pronounced scavenging capacities than ascorbic acid $\left(\mathrm{IC}_{50}=242.6 \mu \mathrm{M}\right)$. Similarly to previous DPPH assay compound $7 \mathrm{e}\left(\mathrm{IC}_{50}=79.3 \mu \mathrm{M}\right)$ showed to be the most potent scavenger of ABTS radical cation which was followed by samples $\mathbf{6 e}$ and $\mathbf{6 h}$. Meanwhile $\mathbf{6 d}$ and $\mathbf{7 h}$ exhibited the weakest scavenging capacities $\left(\mathrm{IC}_{50}=120.1 \mu \mathrm{M}\right.$ and $\mathrm{IC}_{50}=$ $120.6 \mu \mathrm{M}$ respectively).

Hydrogen peroxide is a biologically relevant, oxidizing species which is formed in numerous animal tissues through several oxidative processes and can diffuse across biological membranes, causing oxidative damage to DNA, proteins, lipids and other biomolecules. According to our results presented in Table 2 all tested compounds showed weaker $\mathrm{H}_{2} \mathrm{O}_{2}$ scavenging properties than the ascorbic acid $\left(\mathrm{IC}_{50}=22.4 \mu \mathrm{M}\right)$. Among tested samples 6d showed the most prominent scavenging capacity with $\mathrm{IC}_{50}$ value approximately two times higher than the ascorbic acid $\left(\mathrm{IC}_{50}=37.41 \mu \mathrm{M}\right)$. The obtained results are comparable to data collected by Kotaiah et al. ${ }^{16}$ who examined $\mathrm{H}_{2} \mathrm{O}_{2}$ scavenging capacities of 1,3,4-oxidazole tagged thieno[2,3d]pyrimidine derivatives using the same assay. On contrary to our results all compounds examined in the mentioned study exhibited $\mathrm{H}_{2} \mathrm{O}_{2}$ scavenging capacities near to the value obtained for the ascorbic acid $\left(\mathrm{IC}_{50}=16.35\right)$.

Folin-Ciocalteu reducing capacity assay (F-C) has been widespread assay for measurement of total phenolics in natural products, although the basic mechanism is an oxidationreduction process, thus it can be considered as a method suitable for the estimation of antioxidant capacity. ${ }^{27}$ It could be particularly useful for comparison of reducing capacities of natural products and newly synthesized compounds since the results are often expressed in $\mathrm{mg}$ or $\mathrm{g}$ of gallic acid or catechin equivalents per gram of tested sample which allows direct comparison with available literature data. In the present study majority of investigated compounds exhibited a stronger reduction of $\mathrm{F}-\mathrm{C}$ complex than gallic acid which was used as standard with the exception of compound 7d which was approximately $10 \%$ less efficient in the reduction of $\mathrm{F}-\mathrm{C}$ reagent than the gallic acid. Sample $\mathbf{6 h}$ possessed the strongest reducing capacity among tested compounds (Table 2).

Considering the results of ferric ion reducing capacity assay (Table 2) it can be observed that all examined compounds showed higher capacities for $\mathrm{Fe}^{3+}$ reduction than ascorbic acid which was used as standard. In concordance with the previous assay compound $\mathbf{7 d}$ exhibited the lowest reduction capacity towards $\mathrm{Fe}^{3+}$ ion and two samples with the strongest reduction capacity were $6 \mathbf{e}$ and $6 \mathbf{h}$.

From the mechanistic standpoint discrepancies in two previous reducing capacity tests and ABTS assay could be explained either by different redox potential of counterparts reacting with the tested antioxidant compounds or by different reaction times needed for reaching the steady-state time point. The difference in steric accessibility of antioxidant compounds to ABTS radical cation, $\mathrm{F}-\mathrm{C}$ complex and $\mathrm{Fe}^{3+}$ ion could be also the possible reason for observed discrepancies between the assays. ${ }^{27}$

Table 3 Concentrations of diacylhydrazines and 1,3,4-oxadiazoles which induced $50 \%$ decrease in MRC-5 cell survival after $72 \mathrm{~h}$ treatment

\begin{tabular}{lr}
\hline Compound & $\mathrm{IC}_{50} \pm \mathrm{SD}[\mu \mathrm{M}]$ \\
\hline $\mathbf{6 d}$ & $118.35 \pm 9.41$ \\
$\mathbf{6 e}$ & $194.27 \pm 2.69$ \\
$\mathbf{6 g}$ & $86.33 \pm 2.41$ \\
$\mathbf{6 h}$ & $91.83 \pm 8.57$ \\
$\mathbf{7 d}$ & $26.88 \pm 1.66$ \\
$\mathbf{7 e}$ & $37.49 \pm 0.20$ \\
$\mathbf{7 g}$ & $34.88 \pm 1.93$ \\
$\mathbf{7 h}$ & $25.59 \pm 1.76$ \\
Cisplatin & $9.24 \pm 0.18$
\end{tabular}


A
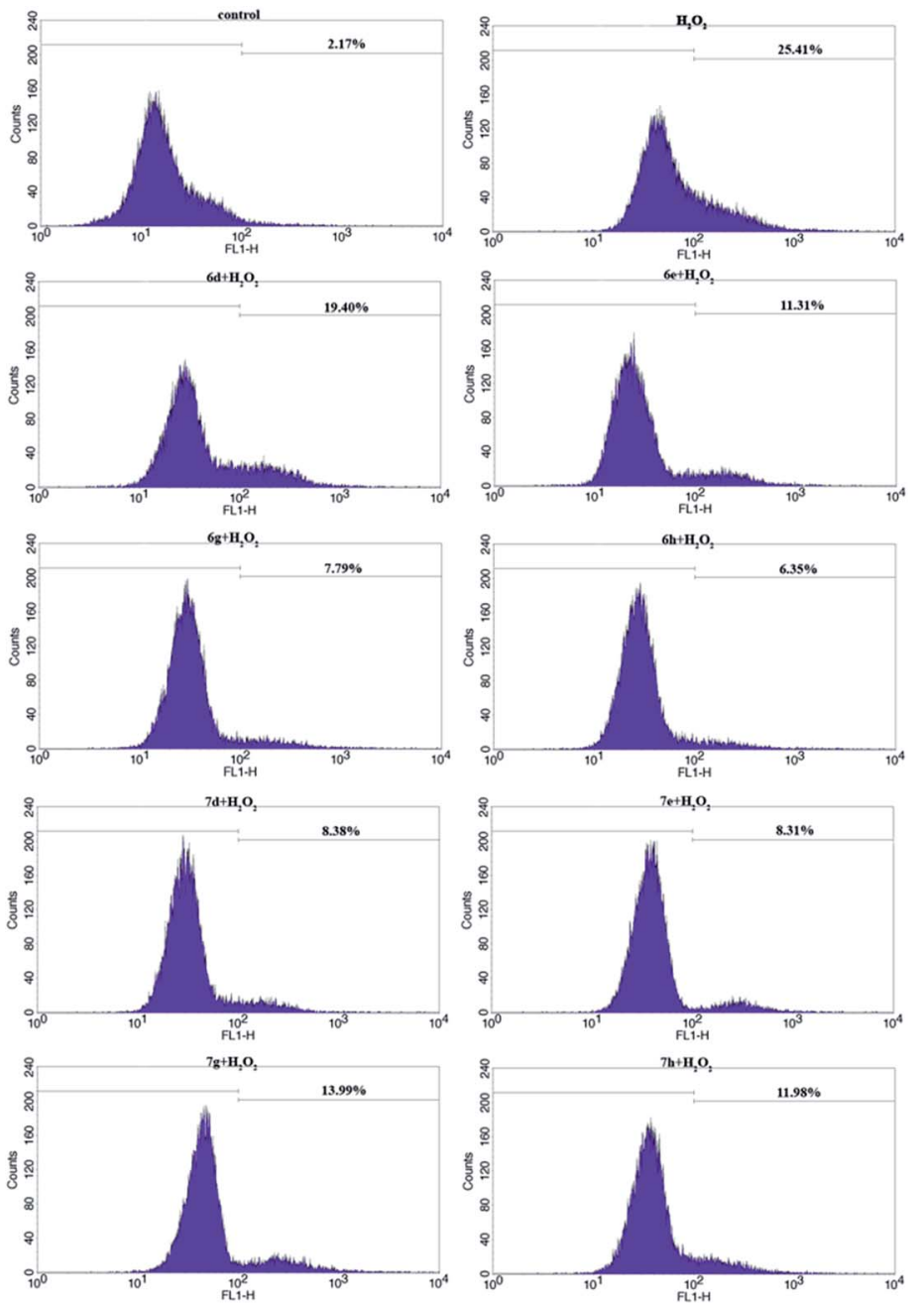

B

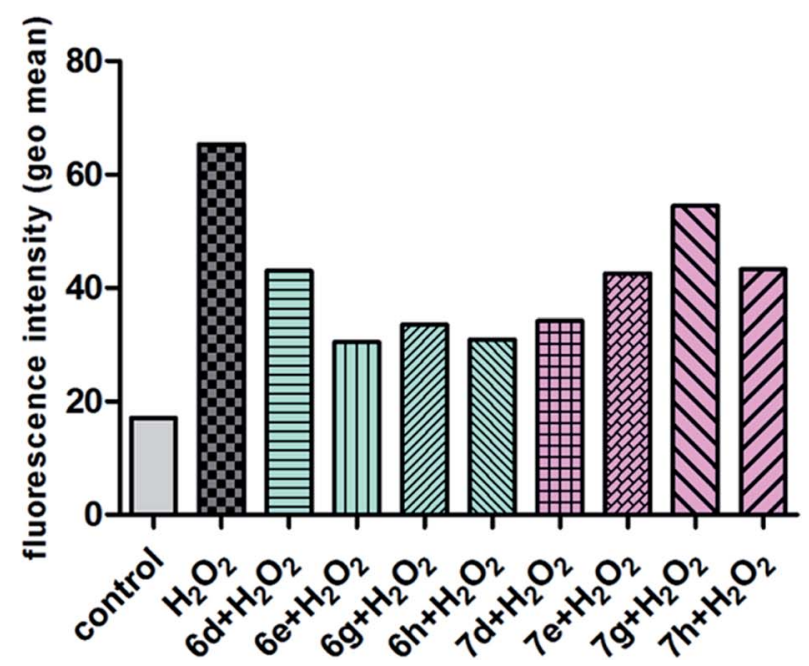

Fig. 1 Effects of $24 \mathrm{~h}$ pretreatment of MRC-5 cells with diacylhydrazines and 1,3,4-oxadiazoles on ROS production induced by hydrogen peroxide. (A) Fluorescence histograms; (B) fluorescence intensity of generated dichlorofluorescein in MRC-5 cells. Applied non-toxic concentrations of compounds were: $50 \mu \mathrm{M}$ for $6 \mathrm{~d}, 6 \mathrm{e}, 6 \mathrm{~g}$ and $6 \mathrm{~h}$, and $20 \mu \mathrm{M}$ for $7 \mathrm{~d}, 7 \mathrm{e}, 7 \mathrm{~g}$ and $7 \mathrm{~h}$. 
Table 4 Activities of antioxidant enzymes in control MRC-5 cells and cells exposed for $24 \mathrm{~h}$ to non-toxic concentrations of investigated diacylhydrazines and 1,3,4-oxadiazoles

\begin{tabular}{|c|c|c|c|}
\hline Control & $10.09 \pm 0.44$ & $1.17 \pm 0.16$ & $2.70 \pm 0.24$ \\
\hline $6 e$ & $7.58 \pm 1.02$ & $0.87 \pm 0.09$ & $2.53 \pm 0.14$ \\
\hline $6 g$ & $5.67 \pm 0.33$ & $0.05 \pm 0.02$ & $2.57 \pm 0.23$ \\
\hline $6 \mathrm{~h}$ & $3.48 \pm 0.07$ & $2.26 \pm 0.21$ & $2.66 \pm 0.31$ \\
\hline $7 g$ & $0.86 \pm 0.17$ & $0.37 \pm 0.07$ & $2.73 \pm 0.22$ \\
\hline $7 \mathbf{h}$ & $1.18 \pm 0.11$ & $0.37 \pm 0.10$ & $2.79 \pm 0.30$ \\
\hline
\end{tabular}

\subsection{Cytotoxic activity of diacylhydrazines and 1,3,4- oxadiazoles on MRC-5 cells}

All synthesized compounds which exerted the most intensive antioxidant effects as shown by DPPH assay, were chosen for further evaluation of their protective properties in normal cells. For that reason, we first examined the cytotoxic activity of selected diacylhydrazines $\mathbf{6 d}, \mathbf{6 e}, \mathbf{6 g}, \mathbf{6 h}$, and 1,3,4-oxadiazoles $\mathbf{7 d}, \mathbf{7 e}, \mathbf{7 g}$ and $\mathbf{7 h}$ against normal human lung fibroblasts MRC-5 (results are presented in Table 3). Among tested compounds, 1,3,4-oxadiazoles $\mathbf{7 h}$ and $\mathbf{7 d}$ exerted the highest intensity of the cytotoxic activity on MRC-5 cells. The compounds $7 \mathrm{~g}$ and $7 \mathrm{e}$ also showed pronounced cytotoxicity with $\mathrm{IC}_{50}$ values approximately $30 \%$ higher than $\mathbf{7 h}$ and $\mathbf{7 d}$. However, the examined diacylhydrazines exhibited significantly lower cytotoxic effects in comparison with 1,3,4-oxadiazoles. The cytotoxicity of compounds $6 \mathbf{g}$ and $\mathbf{6 h}$ was approximately three times lower than the most active compounds $\mathbf{7 d}$ and $\mathbf{7 h}$. The compound $\mathbf{6 d}$ showed very low cytotoxic activity, while the activity of $6 \mathrm{e}$ was quite poor.

\subsection{Effects of pretreatment of MRC-5 cells with diacylhydrazines and 1,3,4-oxadiazoles on ROS generation induced by $\mathrm{H}_{2} \mathrm{O}_{2}$}

To fully evaluate the antioxidant potential of synthesized diacylhydrazines and 1,3,4-oxadiazoles, their possible cytoprotective effects against the generation of ROS induced by hydrogen peroxide were examined in normal human lung fibroblasts MRC5 . As it could be seen in Fig. 1, pretreatment for $24 \mathrm{~h}$ of MRC-5 cells with non-toxic concentrations of all tested compounds (50 $\mu \mathrm{M}$ for diacylhydrazines and $20 \mu \mathrm{M}$ for 1,3,4-oxadiazoles, as determined for $24 \mathrm{~h}$ treatment) reduced the levels of ROS in MRC5 cells treated for 30 min with $\mathrm{H}_{2} \mathrm{O}_{2}$ compared with cells that were grown in the nutrient medium during $24 \mathrm{~h}$ and then exposed to $\mathrm{H}_{2} \mathrm{O}_{2}$. The percentages labeled in each histogram represent the subpopulation of cells with increased fluorescence levels, i.e. with increased levels of ROS. The effectiveness of diacylhydrazines and 1,3,4-oxadiazoles in attenuating the oxidative stress in normal fibroblasts in addition to the results of the antioxidant assays suggest the significant antioxidant potential of the investigated compounds. Higher intracellular level of ROS is implicated in the early steps of malignant transformation, as well as in the further progression of malignant tumors. ${ }^{28}$ Due to their prominent antioxidant effects, and especially the ability to reduce intracellular ROS levels, the examined 1,3,4-oxadiazoles and their diacylhydrazine precursors might serve as an useful cancer chemopreventive agents.

\subsection{Effects of diacylhydrazines and 1,3,4-oxadiazoles on the activity of antioxidant enzymes}

Several enzymatic defense mechanisms attempt to minimize the production and the action of harmful oxidants, such as superoxide dismutase (SOD), glutathione reductase (GR) and glutathione peroxidase (GPX). SOD dismutates the free radical superoxide by converting it to hydrogen peroxide, which in turn is decomposed by catalase at high concentration, and by GPX at low concentration. Most hydrogen peroxide in the cell is generated through the dismutation of superoxide by SOD action, even though it can be produced by other superoxidegenerating enzymes. ${ }^{29,30}$ In our experiments we also investigated the effects of 1,3,4-oxadiazoles and their diacylhydrazine precursors derived from phenolic acids on the activities of antioxidant enzymes, GR, GPX and SOD in MRC-5 cells (Table 4). It is evident that applied compounds drastically reduced the activity of enzymes involved in glutathione metabolism - GR and GPX. The only exception is diacylhydrazine $\mathbf{6 h}$ which increased two times the GPX activity in exposed cells in comparison with the control cell sample. However, no significant changes were noticed on SOD activity. The decrease in GPX activity could suggest inactivation by ROS. ${ }^{31}$ Superoxide anions have been shown to inhibit GPX. ${ }^{32}$ However, it is more likely that such decrease in the activity of GR and GPX could be attributed to other mechanisms, not to the production of ROS, having in mind that there were no changes in SOD activity during applied treatment. It is well known that some 1,3,4oxadiazoles, but only small group of them, could inhibit the enzymes of glutathione metabolism, dominantly GR. ${ }^{33}$ That is very important for using of 1,3,4-oxadiazoles and their derivatives as anthelmintic agents.

\section{Conclusion}

Four diacylhydrazines (6d, 6e, 6g, and $\mathbf{6 h}$ ) and four 1,3,4-oxadiazoles (7d, 7e, $\mathbf{7 g}$ and $\mathbf{7 h}$ ) showing the best DPPH scavenging 
activity, with $\mathrm{IC}_{50}$ values in the range of 13.59 to $22.17 \mu \mathrm{M}$ were selected for further evaluation of their antioxidant potential through various assays. The excellent ABTS radical scavenging potential displayed compounds $\mathbf{6 h}, \mathbf{6 e}$ and $7 \mathbf{e}$. Considering the structures of the compounds which showed the strongest antioxidant activity (6d, 6e, 6g, 6h, 7d, 7e, 7g and 7h), it can be noticed that they all contain two neighboring hydroxyl groups having the possibility to form an intramolecular hydrogen bond. The most potent compound 7e possesses two hydroxyl groups in $m$ - and $p$-positions of the aromatic ring, while the presence of additional hydroxyl groups induces a slight decrease of activity ( $7 \mathbf{g}$ and $7 \mathbf{h}$ ). The compounds $\mathbf{6 d}, \mathbf{6 e}, \mathbf{6 g}$ and 6h possessed moderate to good $\mathrm{H}_{2} \mathrm{O}_{2}$ scavenging properties; the most potent was compound $\mathbf{6 d}$. The diacylhydrazines $\mathbf{6 e}$ and $\mathbf{6 h}$ showed the strongest ferric ion reducing capacities. In addition, the majority of compounds exhibited a stronger reduction of F-C complex than gallic acid; among them, compound $\mathbf{6 h}$ had the strongest capacity. The tested compounds applied at nontoxic concentrations showed the ability to reduce intracellular levels of oxidative stress induced by hydrogen peroxide in normal human lung fibroblasts MRC-5. Non-toxic concentrations of the examined compounds reduced the activities of glutathione reductase and glutathione peroxidase in treated MRC-5 cells. The exception was diacylhydrazine $\mathbf{6 h}$ which increased two times the activity of glutathione peroxidase in treated cells in comparison with control sample. However, the compounds did not affect the superoxide dismutase activity. Results of our study point out the significant antioxidant potential of selected 1,3,4-oxadiazole derivatives and their diacylhydrazine precursors, especially of compounds $\mathbf{6 h}$ and $7 \mathbf{e}$.

\section{Experimental}

\subsection{Physical measurements and methods}

Melting points were determined on a Mel-Temp capillary melting points apparatus, model 1001 and are uncorrected. Elemental (C, H, N, S) analysis of the samples was carried out in the Center for Instrumental Analysis, Faculty of Chemistry, Belgrade. UV spectra were recorded using an Agilent Technologies, Cary 300 Series UV-Vis Spectrophotometer. IR spectra were obtained on a Perkin Elmer Spectrum One FT-IR spectrometer with a $\mathrm{KBr}$ disc. ${ }^{1} \mathrm{H}$ and ${ }^{13} \mathrm{C}$-NMR spectra were taken on a Varian Gemini $200 \mathrm{MHz}$ spectrometer.

\subsection{Procedure for the preparation of $7 a-h$}

4.2.1. Preparation of $\mathbf{5 a}-\mathbf{h}$. The mixture of a corresponding aromatic acid $\mathbf{1 a}-\mathbf{h}(16.00 \mathrm{mmol})$ and $\mathrm{H}_{2} \mathrm{SO}_{4}(0.7 \mathrm{~mL})$ in methanol $(10 \mathrm{~mL})$ was refluxed for $5 \mathrm{~h}$. After evaporation of methanol, water is added and crude ester was extracted with EtOAc $(3 \times 15 \mathrm{~mL})$. The organic layer was washed with $\mathrm{NaHCO}_{3}$ $(15 \mathrm{~mL})$ and $\mathrm{H}_{2} \mathrm{O}(15 \mathrm{~mL})$, dried with $\mathrm{Na}_{2} \mathrm{SO}_{4}$, filtered and the solvent was evaporated in vacuo giving the corresponding ester $\mathbf{2 a}-\mathbf{h}$. The ester of the corresponding aromatic acid $\mathbf{2 a - h}(8.00$ $\mathrm{mmol}$ ) and hydrazine hydrate $(1.2 \mathrm{~mL}, 24.00 \mathrm{mmol})$ in EtOH (30 $\mathrm{mL}$ ) were refluxed for $12 \mathrm{~h}$. Then, the solvent was evaporated, a small amount of water was added $(2 \mathrm{~mL})$ and the suspension was filtrated giving $\mathbf{5 a - h}$.

4.2.2. Preparation of $7 \mathbf{a}-\mathbf{h}$. To the mixture of a corresponding aromatic acid $\mathbf{3 a}-\mathbf{h}(1.00 \mathrm{mmol})$ in dry dichloromethane $(4.0 \mathrm{~mL}), \mathrm{SOCl}_{2}(0.3 \mathrm{~mL}, 4.00 \mathrm{mmol})$ was slowly added, followed by two drops of dimethylformamide. The resulting mixture was then stirred for $2 \mathrm{~h}$ at room temperature. Afterwards, the solvent was evaporated under reduced pressure, and the excess of $\mathrm{SOCl}_{2}$ was removed by azeotropic distillation with toluene. To the formed acid chloride $\mathbf{4 a}-\mathbf{h}(1.00 \mathrm{mmol})$, a corresponding acid hydrazide $\mathbf{5 a}-\mathbf{h}(1.30 \mathrm{mmol})$ and dry tetrahydrofuran $(10.0 \mathrm{~mL})$ were added, and resulting mixture was stirred at room temperature for $6 \mathrm{~h}$. Then, the solvent was evaporated under reduced pressure, small amount of water was added $(2 \mathrm{~mL})$ and the formed precipitate $(\mathbf{6 a}-\mathbf{h})$ was isolated by filtration and dried over $\mathrm{CaCl}_{2}$. The mixture of $\mathbf{6 a}-\mathbf{h}(1.00 \mathrm{mmol})$ in $\mathrm{SOCl}_{2}(6.00 \mathrm{~mL})$ was then refluxed for $6 \mathrm{~h}$. After cooling, the ice was added to the solution and formed suspension was stirred at room temperature for $30 \mathrm{~min}$ and left standing overnight at $4{ }^{\circ} \mathrm{C}$ and compound $\mathbf{7} \mathbf{a}-\mathbf{h}$ was filtered off and dried over $\mathrm{CaCl}_{2}$. The final compounds $7 \mathbf{a}-\mathbf{h}$ needed further purification by recrystallization from hot aqueous solution of $45 \% \mathrm{EtOH}$.

4.2.2.1. $\quad \mathrm{N}^{\prime}$-Benzoyl-2-hydroxybenzohydrazide $\times 0.5 \mathrm{H}_{2} \mathrm{O}(\mathbf{6 a})$. White powder; yield: $0.24 \mathrm{~g}$ (89\%); mp: >250 ${ }^{\circ} \mathrm{C}$; ${ }^{1} \mathrm{H}$ NMR $(200$ MHz, DMSO-d $\left.{ }_{6}\right)$ : 6.92-7.00, (m, 2H, Ar-H); 7.43-7.62, (m, 4H, Ar$\mathrm{H})$; 7.93, (dd, 3H, $J=7.9$ and $1.2 \mathrm{~Hz}, \mathrm{Ar}-\mathrm{H})$; 10.69, (s, 2H, NH); 11.95, (s, 1H, NH); ${ }^{13} \mathrm{C}$ NMR (50 MHz, DMSO-d 6 ): 114.7, 117.5, 119.1, 127.6 (2C), 128.4, 128.6 (2C), 132.0, 132.8, 134.2, 159.4, 165.7, 167.8; IR (KBr, cm $\left.{ }^{-1}\right): 3304 ; 3058 ; 1657 ; 1635 ; 1548 ; 1480$; 1283; 759; anal. calcd for $\mathrm{C}_{14} \mathrm{H}_{12} \mathrm{~N}_{2} \mathrm{O}_{3} \times 0.5 \mathrm{H}_{2} \mathrm{O}(265.27 \mathrm{~g}$ $\mathrm{mol}^{-1}$ ): C, 63.39; H, 4.94; N, 10.56; found: C, 63.53; H, 4.92; N, 10.60 .

4.2.2.2. $\quad \mathrm{N}^{\prime}$-Benzoyl-3-hydroxybenzohydrazide $\times 0.5 \mathrm{H}_{2} \mathrm{O}(\mathbf{6} \boldsymbol{b})$. Beige powder; yield: $0.20 \mathrm{~g}$ (74\%); mp: $>250{ }^{\circ} \mathrm{C}$; for ${ }^{1} \mathrm{H}$ and ${ }^{13} \mathrm{C}$ NMR see ref. 34 or our spectral data placed in ESI. $\dagger$

4.2.2.3. $\quad N^{\prime}$-Benzoyl-4-hydroxy-3-methoxybenzohydrazide $\times$ $0.5 \mathrm{H}_{2} \mathrm{O}(6 \mathrm{c})$. Beige powder; yield: $0.18 \mathrm{~g}(60 \%)$; mp: $219-220{ }^{\circ} \mathrm{C}$; ${ }^{1} \mathrm{H}$ NMR (200 MHz, DMSO-d 6 ): 3.83, (s, 3H, $\left.\mathrm{CH}_{3}\right) ; 6.86,(\mathrm{~d}, 1 \mathrm{H}, J$ $=8.2 \mathrm{~Hz}, \mathrm{Ar}-\mathrm{H}) ; 7.42-7.60,(\mathrm{~m}, 5 \mathrm{H}, \mathrm{Ar}-\mathrm{H})$; 7.92, (dd, 2H, $J=7.4$ and $1.6 \mathrm{~Hz}, \mathrm{Ar}-\mathrm{H})$; 9.73, (s, 1H, OH); 10.28, (s, 1H, NH); 10.42, (s, $1 \mathrm{H}, \mathrm{NH}) ;{ }^{13} \mathrm{C}$ NMR $(50 \mathrm{MHz}$, DMSO-d 6 ): 55.8, 111.6, 115.1, 121.3, 123.6, 127.5 (2C), 128.5 (2C), 131.8, 132.9, 147.3, 150.2, 165.6, 166.0; IR (KBr, $\mathrm{cm}^{-1}$ ): 3218; 3009; 1633; 1593; 1513; 1287; 690; anal. calcd for $\mathrm{C}_{15} \mathrm{H}_{14} \mathrm{~N}_{2} \mathrm{O}_{4} \times 0.5 \mathrm{H}_{2} \mathrm{O}\left(295.29 \mathrm{~g} \mathrm{~mol}^{-1}\right)$ : $\mathrm{C}, 61.01$; $\mathrm{H}, 5.12$; N, 9.49; found: C, 60.94; H, 5.14; N, 9.47.

4.2.2.4. $\quad \mathrm{N}^{\prime}$-Benzoyl-2,3-dihydroxybenzohydrazide $\times 0.5 \mathrm{H}_{2} \mathrm{O}$ (6d). White powder; yield: $0.23 \mathrm{~g}$ (82\%); mp: 226-227 ${ }^{\circ} \mathrm{C}$ (Dec.); ${ }^{1} \mathrm{H}$ NMR (200 MHz, DMSO-d 6 ): 6.76, (t, $\left.1 \mathrm{H}, J=7.8 \mathrm{~Hz}, \mathrm{Ar}-\mathrm{H}\right)$; 6.99, (dd, $1 \mathrm{H}, J=7.8$ and $1.2 \mathrm{~Hz}, \mathrm{Ar}-\mathrm{H}) ; 7.39$, (dd, $1 \mathrm{H}, J=8.0$ and $1.2 \mathrm{~Hz}, \mathrm{Ar}-\mathrm{H})$; 7.49-7.66, (m, 1H, Ar-H); 7.93, (dd, 2H, $J=7.4$ and $1.6 \mathrm{~Hz}, \mathrm{Ar}-\mathrm{H})$; 9.38, (s, 1H, OH); 10.64, (s, 1H, NH); 10.72, (s, $1 \mathrm{H}, \mathrm{NH}) ; 11.96,(\mathrm{~s}, 1 \mathrm{H}, \mathrm{OH}) ;{ }^{13} \mathrm{C}$ NMR (50 MHz, DMSO-d 6 ): 114.3, 117.7, 118.6, 119.5, 127.6 (2C), 128.6 (2C), 132.0, 132.5, 146.3, 149.2, 165.8, 168.9; IR ( $\left.\mathrm{KBr}, \mathrm{cm}^{-1}\right): 3434 ; 3224 ; 3057$; $1636 ; 1602 ; 1579 ; 1535 ; 1310 ; 1265 ; 737$; anal. calcd for $\mathrm{C}_{14} \mathrm{H}_{12} \mathrm{~N}_{2} \mathrm{O}_{4} \times 0.5 \mathrm{H}_{2} \mathrm{O}\left(281.27 \mathrm{~g} \mathrm{~mol}^{-1}\right): \mathrm{C}, 59.78 ; \mathrm{H}, 4.66 ; \mathrm{N}$, 9.96; found: C, 59.73; H, 4.67; N, 9.93. 
4.2.2.5. $\quad N^{\prime}$-Benzoyl-3,4-dihydroxybenzohydrazide $\times 1.5 \mathrm{H}_{2} \mathrm{O}$ (6e). Beige powder; yield: $0.17 \mathrm{~g}(57 \%)$; mp: $166-167{ }^{\circ} \mathrm{C} ;{ }^{1} \mathrm{H}$ NMR $\left(200 \mathrm{MHz}, \mathrm{DMSO}_{6}\right)_{6}: 6.80,(\mathrm{~d}, 1 \mathrm{H}, J=8.2 \mathrm{~Hz}, \mathrm{Ar}-\mathrm{H}) ; 7.29,(\mathrm{~d}, 1 \mathrm{H}$, $J=8.2$ and $2.0 \mathrm{~Hz}, \mathrm{Ar}-\mathrm{H}) ; 7.34,(\mathrm{~d}, 1 \mathrm{H}, J=2.0 \mathrm{~Hz}, \mathrm{Ar}-\mathrm{H}) ; 7.46-$ 7.59, (m, 3H, Ar-H); 7.91, (dd, 2H, J=7.2 and $1.6 \mathrm{~Hz}, \mathrm{Ar}-\mathrm{H}) ; 9.25$, (s, 1H, OH); 9.59, (s, 1H, OH); 10.16, (s, 1H, NH); 10.36, (s, 1H, $\mathrm{NH}) ;{ }^{13} \mathrm{C}$ NMR (50 MHz, DMSO-d 6 ): 115.1, 115.5, 119.5, 123.9, 127.5 (2C), 128.5 (2C), 131.8, 132.9; 145.1, 149.0, 165.9, 166.0; IR $\left(\mathrm{KBr}, \mathrm{cm}^{-1}\right): 3215 ; 3055 ; 1618 ; 1600 ; 1576 ; 1516 ; 1489 ; 1296 ; 688$; anal. calcd for $\mathrm{C}_{14} \mathrm{H}_{12} \mathrm{~N}_{2} \mathrm{O}_{4} \times 1.5 \mathrm{H}_{2} \mathrm{O}\left(299.28 \mathrm{~g} \mathrm{~mol}^{-1}\right)$ : C, 56.38; $\mathrm{H}, 4.73$; N, 9.32; found: C, 56.40; H, 4.74; N, 9.34.

4.2.2.6. $\quad N^{\prime}$-Benzoyl-3,5-dihydroxybenzohydrazide (6f). Light beige powder; yield: $0.23 \mathrm{~g}$ (84\%); mp: >250 ${ }^{\circ} \mathrm{C} ;{ }^{1} \mathrm{H}$ NMR $(200$ MHz, DMSO-d $\left.{ }_{6}\right): 6.41$, (t, $\left.1 \mathrm{H}, J=2.2 \mathrm{~Hz}, \mathrm{Ar}-\mathrm{H}\right) ; 6.75$, (d, $2 \mathrm{H}, J=$ $2.2 \mathrm{~Hz}, \mathrm{Ar}-\mathrm{H}) ; 7.47-7.60,(\mathrm{~m}, 3 \mathrm{H}, \mathrm{Ar}-\mathrm{H}) ; 7.91$, (dd, $2 \mathrm{H}, J=8.0$ and $1.6 \mathrm{~Hz}, \mathrm{Ar}-\mathrm{H})$; 9.56, (s, 2H, OH); 10.26, (s, 1H, NH); 10.41, (s, 1H, $\mathrm{NH}) ;{ }^{13} \mathrm{C}$ NMR (50 MHz, DMSO-d 6 ): 105.8 (3C), 127.5 (2C), 128.5 (2C), 131.8, 132.8, 134.9; 158.5 (2C); 165.8; 166.2; IR (KBr, $\left.\mathrm{cm}^{-1}\right)$ : 3340, 3198; 1676; 1649; 1599; 1541; 1501; 1160; 706; anal. calcd for $\mathrm{C}_{14} \mathrm{H}_{12} \mathrm{~N}_{2} \mathrm{O}_{4}\left(272.26 \mathrm{~g} \mathrm{~mol}^{-1}\right)$ : C, 61.76; H, 4.44; N, 10.29; found: C, 61.73; H, 4.45; N, 10.31 .

4.2.2.7. 3,4-Dihydroxy- $N^{\prime}$-(2-hydroxybenzoyl)benzohydrazide $\times$ $1.5 \mathrm{H}_{2} \mathrm{O}(6 \mathrm{~g})$. Beige powder; yield: $0.28 \mathrm{~g}(88 \%) ; \mathrm{mp}:>250{ }^{\circ} \mathrm{C} ;{ }^{1} \mathrm{H}$ NMR (200 MHz, DMSO-d 6 ): 6.81, (d, 1H, J=8.2 Hz, Ar-H); 6.916.99, (m, 2H, Ar-H); 7.29, (dd, $1 \mathrm{H}, J=8.2$ and $2.0 \mathrm{~Hz}, \mathrm{Ar}-\mathrm{H}) ; 7.34$, $(\mathrm{d}, 1 \mathrm{H}, J=2.0 \mathrm{~Hz}, \mathrm{Ar}-\mathrm{H}) ; 7.46$, (td, $1 \mathrm{H}, J=8.0$ and $1.6 \mathrm{~Hz}, \mathrm{Ar}-\mathrm{H})$; 7.92, (dd, $1 \mathrm{H}, J=8.0$ and $1.6 \mathrm{~Hz}, \mathrm{Ar}-\mathrm{H}) ; 9.27$, (s, 1H, OH); 9.63, (s, 1H, OH); 10.32, (s, 1H, NH); 10.58, (s, 1H, NH); 12.03, (s, 1H, OH); ${ }^{13} \mathrm{C}$ NMR (50 MHz, DMSO-d ${ }_{6}$ ): 114.7, 115.2, 115.4, 117.5, 119.1, 119.6, 123.5, 128.3, 134.2, 145.1, 149.2, 159.5, 165.6, 168.0; IR $\left(\mathrm{KBr}, \mathrm{cm}^{-1}\right): 3288,3055 ; 2956 ; 1638 ; 1605 ; 1526 ; 1489 ; 1302 ; 1219$; 754; anal. calcd for $\mathrm{C}_{14} \mathrm{H}_{12} \mathrm{~N}_{2} \mathrm{O}_{5} \times 1.5 \mathrm{H}_{2} \mathrm{O}\left(315.28 \mathrm{~g} \mathrm{~mol}^{-1}\right): \mathrm{C}$, 53.34; H, 4.80; N, 8.88; found: C, 53.35; H, 4.79; N, 8.90.

4.2.2.8. $\quad N^{\prime}$-(3,5-Dihydroxybenzoyl)-3,4-dihydroxybenzohydrazide $\times 0.5 \mathrm{H}_{2} \mathrm{O}$ (6h). Beige powder; yield: $0.19 \mathrm{~g}(62 \%) ; \mathrm{mp}:>250{ }^{\circ} \mathrm{C} ;{ }^{1} \mathrm{H}$ NMR (200 MHz, DMSO-d $\left.)_{6}\right): 6.39$, (t, $\left.1 \mathrm{H}, J=2.2 \mathrm{~Hz}, \mathrm{Ar}-\mathrm{H}\right) ; 6.73$, (d, $1 \mathrm{H}, J=2.2 \mathrm{~Hz}, \mathrm{Ar}-\mathrm{H}) ; 6.79$, (d, $1 \mathrm{H}, J=8.2 \mathrm{~Hz}, \mathrm{Ar}-\mathrm{H}) ; 7.27$, (dd, $1 \mathrm{H}, J$ $=8.2$ and $2.0 \mathrm{~Hz}, \mathrm{Ar}-\mathrm{H}) ; 7.33,(\mathrm{~d}, 1 \mathrm{H}, J=2.0 \mathrm{~Hz}, \mathrm{Ar}-\mathrm{H}) ; 9.24,(\mathrm{~s}, 1 \mathrm{H}$, $\mathrm{OH}) ; 9.54$, (s, 2H, OH); 9.58, (s, 1H, OH); 10.06, (s, 1H, NH); 10.11, (s, $1 \mathrm{H}, \mathrm{NH}) ;{ }^{13} \mathrm{C}$ NMR (50 MHz, DMSO-d $\left.{ }_{6}\right): 105.7,105.8$ (2C), 115.1, 115.5, 119.5, 124.0, 135.1, 145.1, 149.0, 158.4 (2C), 165.7, 166.3; IR $\left(\mathrm{KBr}, \mathrm{cm}^{-1}\right): 3385 ; 3279 ; 1598 ; 1508 ; 1299 ; 1168 ; 859$; anal. calcd for $\mathrm{C}_{14} \mathrm{H}_{12} \mathrm{~N}_{2} \mathrm{O}_{6} \times 0.5 \mathrm{H}_{2} \mathrm{O}\left(313.27 \mathrm{~g} \mathrm{~mol}^{-1}\right)$ : C, 53.68; H, 4.18; N, 8.94; found: C, 53.66; H, 4.19; N, 8.92.

4.2.2.9. 2-(5-Phenyl-1,3,4-oxadiazol-2-yl)phenol (7a). White powder; yield: $0.16 \mathrm{~g}$ (66\%); mp: $158-159{ }^{\circ} \mathrm{C}$; for ${ }^{1} \mathrm{H}$ and ${ }^{13} \mathrm{C}$ NMR see ref. 35 or our spectral data placed in ESI. $\dagger$

4.2.2.10. 3-(5-Phenyl-1,3,4-oxadiazol-2-yl)phenol $\times 0.5 \mathrm{H}_{2} \mathrm{O}$ (7b). Beige powder; yield: $0.14 \mathrm{~g}(56 \%)$; mp: $179-180{ }^{\circ} \mathrm{C}$; for ${ }^{1} \mathrm{H}$ and ${ }^{13} \mathrm{C}$ NMR see ref. 34 or our spectral data placed in ESI. $\dagger$

4.2.2.11. 2-Methoxy-4-(5-phenyl-1,3,4-oxadiazol-2-yl)phenol $\times$ $2.5 \mathrm{H}_{2} \mathrm{O}$ (7c). Grey powder; yield: $0.17 \mathrm{~g}(53 \%) ; \mathrm{mp}: 162-163{ }^{\circ} \mathrm{C} ;{ }^{1} \mathrm{H}$ NMR (200 MHz, DMSO-d $\left.{ }_{6}\right): 3.90,\left(\mathrm{~s}, 3 \mathrm{H}, \mathrm{CH}_{3}\right) ; 6.99,(\mathrm{~d}, 1 \mathrm{H}, J=$ 8.8 Hz, Ar-H); 7.58-7.65, (m, 5H, Ar-H); 8.11-8.15, (m, 2H, Ar-H); 9.99, (s, 1H, OH); ${ }^{13} \mathrm{C}$ NMR (50 MHz, DMSO-d $\mathrm{d}_{6}$ ): 56.0, 110.4, 114.4, 116.2, 120.7, 123.6, 126.6 (2C), 129.5 (2C), 131.9, 148.3,
150.6, 163.5, 164.4; IR (KBr, $\left.\mathrm{cm}^{-1}\right): 3432 ; 3204 ; 1600 ; 1502 ; 1432$; 1288; 726; anal. calcd for $\mathrm{C}_{15} \mathrm{H}_{12} \mathrm{~N}_{2} \mathrm{O}_{3} \times 2.5 \mathrm{H}_{2} \mathrm{O}\left(313.31 \mathrm{~g} \mathrm{~mol}^{-1}\right)$ : C, 57.50; H, 5.47; N, 8.94; found: C, 57.53; H, 5.46; N, 8.96.

4.2.2.12. 3-(5-Phenyl-1,3,4-oxadiazol-2-yl)benzene-1,2-diol (7d). Beige crystals; yield: $0.15 \mathrm{~g}$ (58\%); mp: $172-173{ }^{\circ} \mathrm{C}$; for ${ }^{1} \mathrm{H}$ and ${ }^{13} \mathrm{C}$ NMR see ref. 36 or our spectral data placed in ESI. $\dagger$

4.2.2.13. 4-(5-Phenyl-1,3,4-oxadiazol-2-yl)benzene-1,2-diol $\times$ $2 \mathrm{H}_{2} \mathrm{O}$ (7e). Beige powder; yield: $0.16 \mathrm{~g}(56 \%)$; mp: $220-221{ }^{\circ} \mathrm{C} ;{ }^{1} \mathrm{H}$ NMR (200 MHz, DMSO-d $)_{6}$ : 6.93, (d, 1H, $\left.J=8.0 \mathrm{~Hz}, \mathrm{Ar}-\mathrm{H}\right) ; 7.45$, (dd, $1 \mathrm{H}, J=8.0$ and $2.0 \mathrm{~Hz}, \mathrm{Ar}-\mathrm{H}) ; 7.50,(\mathrm{~d}, 1 \mathrm{H}, J=2.0 \mathrm{~Hz}, \mathrm{Ar}-\mathrm{H})$; 7.61-7.64, (m, 3H, Ar-H); 8.05-8.10, (m, 2H, Ar-H); 9.58, (s, 1H, $\mathrm{OH}) ; 9.86,(\mathrm{~s}, 1 \mathrm{H}, \mathrm{OH}) ;{ }^{13} \mathrm{C}$ NMR (50 MHz, DMSO-d $\left.\mathrm{d}_{6}\right): 113.8$, 114.4, 116.4, 119.1, 123.7, 126.6 (2C), 129.5 (2C), 131.9; 146.0, 149.5, 163.4, 164.5; IR (KBr, cm $\left.{ }^{-1}\right): 3421 ; 3253 ; 1608 ; 1506 ; 1448$; 1296; 698; anal. calcd for $\mathrm{C}_{14} \mathrm{H}_{10} \mathrm{~N}_{2} \mathrm{O}_{3} \times 2 \mathrm{H}_{2} \mathrm{O}\left(290.28 \mathrm{~g} \mathrm{~mol}^{-1}\right)$ : C, 57.92; H, 4.86; N, 9.65; found: C, 57.90; H, 4.87; N, 9.63.

4.2.2.14. 5-(5-Phenyl-1,3,4-oxadiazol-2-yl)benzene-1,3-diol (7f). Light yellow powder; yield: $0.19 \mathrm{~g}(71 \%)$; mp: $>250{ }^{\circ} \mathrm{C} ;{ }^{1} \mathrm{H}$ NMR (200 MHz, DMSO-d $\left.)_{6}\right): 6.46,(\mathrm{t}, 1 \mathrm{H}, J=2.2 \mathrm{~Hz}, \mathrm{Ar}-\mathrm{H}) ; 6.98,(\mathrm{~d}, 2 \mathrm{H}, J$ $=2.2 \mathrm{~Hz}, \mathrm{Ar}-\mathrm{H})$; 7.62-7.66, (m, 3H, Ar-H); 8.06-8.11, (m, 2H, Ar$\mathrm{H}) ; 9.84,(\mathrm{~s}, 2 \mathrm{H}, \mathrm{OH}) ;{ }^{13} \mathrm{C}$ NMR (50 MHz, DMSO-d $\left.\mathrm{d}_{6}\right): 104.8$ (2C), 106.2, 123.5, 124.7, 126.7 (2C), 129.5 (2C); 132.1; 159.3 (2C); 163.9; 164.3; IR (KBr, cm ${ }^{-1}$ ): 3493, 3386; 3102; 1624; 1608; 1567; 1555; 1448 ; 1160; 853; anal. calcd for $\mathrm{C}_{14} \mathrm{H}_{10} \mathrm{~N}_{2} \mathrm{O}_{3} \times \mathrm{H}_{2} \mathrm{O}(272.26 \mathrm{~g}$ $\mathrm{mol}^{-1}$ ): C, 61.76; H, 4.44; N, 10.29; found: C, 61.75; H, 4.43; N, 10.27 .

4.2.2.15. 4-(5-(2-Hydroxyphenyl)-1,3,4-oxadiazol-2-yl)benzene1,2-diol $\times 0.5 \mathrm{H}_{2} \mathrm{O}(7 \mathrm{~g})$. Light brown powder; yield: $0.22 \mathrm{~g}(78 \%)$; mp: $>250{ }^{\circ} \mathrm{C} ;{ }^{1} \mathrm{H}$ NMR $\left(200 \mathrm{MHz}, \mathrm{DMSO}_{6}\right.$ ): 6.94, (d, $1 \mathrm{H}, J=$ $8.2 \mathrm{~Hz}, \mathrm{Ar}-\mathrm{H})$; 7.00-7.12, (m, 2H, Ar-H); 7.42, (dd, $1 \mathrm{H}, J=8.2$ and 1.6 Hz, Ar-H); 7.47-7.51, (m, 2H, Ar-H); 7.87, (dd, $1 \mathrm{H}, J=8.0$ and $1.0 \mathrm{~Hz}, \mathrm{Ar}-\mathrm{H})$; 9.60, (s, 1H, OH); 9.86, (s, 1H, OH); 10.28, (s, 1H, $\mathrm{OH}) ;{ }^{13} \mathrm{C}$ NMR (50 MHz, DMSO-d 6 ): 109.7, 113.8, 114.2, 116.4, 117.2 , 119.1, 120.0, 128.4, 133.3, 146.0, 149.6, 156.4, 162.9, 163.7; IR (KBr, cm ${ }^{-1}$ ): 3435, 3204; 1615; 1595; 1517; 1491; 1451; $1301 ; 1253$; 746; anal. calcd for $\mathrm{C}_{14} \mathrm{H}_{10} \mathrm{~N}_{2} \mathrm{O}_{4} \times 0.5 \mathrm{H}_{2} \mathrm{O}(279.25 \mathrm{~g}$ $\mathrm{mol}^{-1}$ ): C, 60.21; H, 3.97; N, 10.03; found: C, 60.23; H, 3.96; N, 10.05 .

4.2.2.16. 4-(5-(3,5-Dihydroxyphenyl)-1,3,4-oxadiazol-2-yl)benzene1,2-diol $\times 2 \mathrm{H}_{2} \mathrm{O}$ (7h). Brown powder; yield: $0.18 \mathrm{~g}$ (57\%); mp: $>250{ }^{\circ} \mathrm{C} ;{ }^{1} \mathrm{H}$ NMR $\left(200 \mathrm{MHz}, \mathrm{DMSO}_{6}\right): 6.43$, (t, $1 \mathrm{H}, J=2.0 \mathrm{~Hz}, \mathrm{Ar}^{-}$ $\mathrm{H})$; 6.91-6.95, (m, 3H, Ar-H); 7.38, (d, 1H, $J=8.2$ and $2.0 \mathrm{~Hz}, \mathrm{Ar}-\mathrm{H}$ ); 7.45, (d, 1H, J = 2.0 Hz, Ar-H); 9.58, (s, 1H, OH); 9.81, (s, 3H, OH); ${ }^{13} \mathrm{C}$ NMR (50 MHz, DMSO-d ${ }_{6}$ ): 104.57 (2C), 106.0, 113.7, 114.4, 116.4, 119.0, 125.0, 146.0, 149.5, 159.2 (2C), 163.6, 164.2; IR (KBr, $\left.\mathrm{cm}^{-1}\right): 3237,1605 ; 1573 ; 1505 ; 1453 ; 1285 ; 1162 ; 854$; anal. calcd for $\mathrm{C}_{14} \mathrm{H}_{10} \mathrm{~N}_{2} \mathrm{O}_{5} \times 2 \mathrm{H}_{2} \mathrm{O}\left(322.27 \mathrm{~g} \mathrm{~mol}^{-1}\right)$ : C, 52.18; H, 4.38; N, 8.69; found: C, 52.16; H, 4.37; N, 8.70.

\subsection{DPPH free radical scavenging method}

The antioxidant activity of synthesized diacylhydrazines and 1,3,4-oxadiazoles was evaluated using DPPH free radical scavenging activity method by Kumarasamy et al. ${ }^{37} 1 \mathrm{~mL}$ of methanol solution of DPPH $\left(80 \mathrm{mg} \mathrm{L}^{-1}\right)$ was mixed with the same volume of referent antioxidants and synthesized diacylhydrazines and 1,3,4-oxadiazoles dissolved in methanol. The 
absorbance was measured spectrophotometrically at $517 \mathrm{~nm}$ after incubation for $30 \mathrm{~min}$ in the dark. The DPPH radical scavenging activity of newly synthesized compounds was compared with well - known referent antioxidants, ascorbic acid and NDGA. DPPH radical scavenging activity was calculated as:

$$
\% \text { radical scavenging activity }=\frac{A_{\mathrm{c}}-A_{\mathrm{s}}}{A_{\mathrm{c}}} \times 100,
$$

where $A_{\mathrm{c}}$ is the absorbance of control (DPPH in methanol) and $A_{\mathrm{s}}$ is absorbance of the samples. Results were expressed as the concentration of the compounds providing $50 \%$ of scavenging of DPPH radicals $\left(\mathrm{IC}_{50}\right)$, which were calculated through the sigmoidal dose response curve, as $\mu \mathrm{M}$, using OriginPro8 statistical software. All radical scavenging assays of DPPH were analyzed in triplicates.

\subsection{ABTS radical cation scavenging assay}

For the measurement of total antioxidant capacity of synthesized compounds we have employed automated assay using stable ABTS radical cation described previously by Erel. ${ }^{38}$ Reaction mixture consisted of $200 \mu \mathrm{L}$ of Reagent 1 (acetate buffer $0.4 \mathrm{M}$, pH 5.8) containing $5 \mu \mathrm{L}$ of different sample dilutions prepared in DMSO was mixed with $20 \mu \mathrm{L}$ of Reagent 2 $\left(10 \mathrm{mM} \mathrm{ABTS}^{*+}, 2 \mathrm{mM} \mathrm{H}_{2} \mathrm{O}_{2}\right.$ in $30 \mathrm{mM}$ acetate buffer $\mathrm{pH}$ 3.6. Solution should be prepared $12-16 \mathrm{~h}$ prior to analysis). The first absorbance measurement at $660 \mathrm{~nm}$ was taken before mixing Reagent 1 and Reagent 2 and it served as sample blank, the last absorbance measurement was taken after the incubation period of $5 \mathrm{~min}$ after the mixing two reagents. The control sample consisted of the same reagents with $5 \mu \mathrm{L}$ of DMSO instead of the sample in Reagent 1 . Results were calculated as follows:

$$
\begin{aligned}
\text { ABTS }^{\cdot+} \text { scavenging } \%= & {\left[A_{660 \mathrm{~nm} \text { control }}-A_{660 \mathrm{~nm} \text { sample }}\right] } \\
& / A_{660 \mathrm{~nm} \text { control }} \times 100
\end{aligned}
$$

The antioxidant capacity was expressed as $\mathrm{IC}_{50}$ (concentration of compounds in $\mu \mathrm{M}$ required for $50 \%$ reduction of ABTS radicals).

\section{5. $\mathrm{H}_{2} \mathrm{O}_{2}$ scavenging assay}

For the detection of hydrogen peroxide scavenging activity previously described method of Ruch et al. was employed. ${ }^{39}$ Reaction mixture contained $0.6 \mathrm{~mL} 40 \mathrm{mM} \mathrm{H}_{2} \mathrm{O}_{2}$ in $50 \mathrm{mM}$ phosphate buffer $\mathrm{pH} 7.4$ which was added to $3.4 \mathrm{~mL}$ of the same buffer containing different concentrations of test samples. Upon the addition of peroxide, mixture was shaken vigorously and left to incubate at room temperature for $10 \mathrm{~min}$, than the absorbance was recorded at $230 \mathrm{~nm}$. Control sample consisted of phosphate buffer and $\mathrm{H}_{2} \mathrm{O}_{2}$ without samples. Percent of $\mathrm{H}_{2} \mathrm{O}_{2}$ scavenging was calculated according to the following equation:

$$
\begin{aligned}
\mathrm{H}_{2} \mathrm{O}_{2} \text { scavenging } \%= & {\left[A_{230 \mathrm{~nm} \text { control }}-A_{230 \mathrm{~nm} \text { sample }}\right] } \\
& / A_{230 \mathrm{~nm} \text { control }} \times 100
\end{aligned}
$$

The antioxidant capacity was expressed as $\mathrm{IC}_{50}$ (concentration of compounds in $\mu \mathrm{M}$ required for $50 \%$ reduction of $\mathrm{H}_{2} \mathrm{O}_{2}$ ).

\subsection{F-C reducing capacity assay}

The ability of synthesized compounds to reduce Folin-Ciocalteu's reagent (FC) was measured according to the previously described method of Singleton and Rossi. ${ }^{40}$ The reaction mixture consisted of $1580 \mu \mathrm{L} \mathrm{H}_{2} \mathrm{O}, 20 \mu \mathrm{L}$ sample in DMSO, 100 $\mu \mathrm{L}$ of FC reagent and $300 \mu \mathrm{L}$ of $20 \% \mathrm{Na}_{2} \mathrm{CO}_{3}$ solution. After $2 \mathrm{~h}$ of incubation at room temperature absorbance was measured at $765 \mathrm{~nm}$ and results were expressed as grams of gallic acid equivalents per gram of tested compound (gGAE per g) using gallic acid calibration curve $10-1000 \mu \mathrm{g} \mathrm{mL}{ }^{-1}$ with linearity range $r=0.993$.

\subsection{Ferric ion-reducing capacity assay}

Reducing power of tested compounds was performed according to the method of Pownall et al. ${ }^{41}$ Sample dilutions were prepared in $50 \mathrm{mM}$ phosphate buffer, $\mathrm{pH} 7.0$ and $500 \mu \mathrm{L}$ of dilutions were mixed with $250 \mu \mathrm{L}$ of $1 \%$ potassium ferricyanide solution followed by incubation for $20 \mathrm{~min}$ at $50{ }^{\circ} \mathrm{C}$. After the incubation $500 \mu \mathrm{L}$ of $10 \%$ trichloroacetic acid was mixed with $500 \mu \mathrm{L}$ of the incubated sample, $100 \mu \mathrm{L}$ of $0.1 \%$ ferric chloride and $500 \mu \mathrm{L}$ of distilled water. The mixture was left to incubate for $10 \mathrm{~min}$ at room temperature and the absorbance was immediately measured at $700 \mathrm{~nm}$, against blank, which consisted of phosphate buffer and appropriate volume of solvent. The results were expressed as absorbance units at $700 \mathrm{~nm}$ which was considered as a measure of reducing power.

\subsection{Cell culture}

Human normal lung fibroblasts MRC-5 were cultured as monolayers at $37{ }^{\circ} \mathrm{C}$ in an atmosphere of $5 \% \mathrm{CO}_{2}$ and humidified air. The cell line was purchased from the American Type Culture Collection (Manassas, VA, USA). The nutrient medium was RPMI-1640 supplemented with $2 \mathrm{mM}$ L-glutamine, $100 \mu \mathrm{g}$ $\mathrm{mL}^{-1}$ streptomycin, $100 \mathrm{IU} \mathrm{mL}^{-1}$ penicillin, $10 \%$ heatinactivated $\left(56{ }^{\circ} \mathrm{C}\right)$ fetal bovine serum and $25 \mathrm{mM}$ HEPES, adjusted to $\mathrm{pH} 7.2$ with a bicarbonate solution. RPMI-1640, fetal bovine serum and HEPES were products of Sigma Aldrich (Saint Louis, MO, USA).

\subsection{MTT cell survival assay}

MRC-5 normal lung fibroblasts (5000 cells per well) were seeded in 96-well microtiter plates with flat bottom and $20 \mathrm{~h}$ later, after the cell adherence, five concentrations of the investigated compounds were added to the cells (range from $12.5 \mu \mathrm{M}$ to 200 $\mu \mathrm{M})$. Nutrient medium only was added to the cells in the control wells. Stock solutions of tested compounds were made in dimethyl sulfoxide (DMSO) at a concentration of $10 \mathrm{mM}$. After $72 \mathrm{~h}$ treatment, the survival of MRC- 5 cells was assessed by MTT cell survival test according to the method of Mosmann ${ }^{\mathbf{4 2}}$ and modified by Ohno and Abe, ${ }^{43}$ as described elsewhere by our research group. ${ }^{44}$ 
All experiments were done in triplicate. A chemotherapy drug cisplatin was used as a positive control. The used chemicals were products of Sigma Aldrich.

\subsection{Measurement of intracellular ROS levels}

After $24 \mathrm{~h}$ exposure to non-toxic concentrations of investigated diacylhydrazines and 1,3,4-oxadiazoles (values were determined using MTT test for the $24 \mathrm{~h}$ treatment with compounds), the treated and control MRC-5 cells were loaded with a $30 \mu \mathrm{M} 2^{\prime}, 7^{\prime}$ dichlorodihydrofluorescein diacetate (Sigma Aldrich, catalog number D6883) in a phosphate buffered saline (PBS) for $45 \mathrm{~min}$ at $37{ }^{\circ} \mathrm{C}$. The cells were then washed with PBS and exposed to $2.5 \mathrm{mM}$ hydrogen peroxide solution $\left(\mathrm{H}_{2} \mathrm{O}_{2}\right)$ for $30 \mathrm{~min}$ at $37^{\circ} \mathrm{C}$ to induce generation of ROS. Following incubation with $\mathrm{H}_{2} \mathrm{O}_{2}$, the cell samples were washed with PBS, collected and the intensity of green fluorescence emitted by the generated probe dichlorofluorescein was measured on a FACSCalibur flow cytometer (BD Biosciences Franklin Lakes, NJ, USA). The data (20 000 events acquired for each cell sample) were analysed using CELLQuest software (BD Biosciences). Applied non-toxic concentrations of the investigated compounds were: $50 \mu \mathrm{M}$ for the compounds $6 \mathbf{d}, \mathbf{6 e}, \mathbf{6 g}$ and $\mathbf{6 h}$, and $20 \mu \mathrm{M}$ for the compounds $7 \mathrm{~d}, 7 \mathrm{e}, 7 \mathrm{~g}$ and $7 \mathrm{~h}$.

\subsection{Antioxidative enzymes assay}

MRC-5 cells (control and cell samples exposed for $24 \mathrm{~h}$ to nontoxic concentrations of investigated compounds) were harvested from culture flasks, washed with PBS and centrifuged at $1500 \times g$ for $10 \mathrm{~min}$ at $4{ }^{\circ} \mathrm{C}$. Cell pellets were re-suspended in 0.5 $\mathrm{mL}$ of PBS and then sonicated on ice three times, for $30 \mathrm{~s}$ each. The total extract was centrifuged at $3000 \times g$ for $15 \mathrm{~min}$ at $4{ }^{\circ} \mathrm{C}$. Aliquots of the supernatant were used for enzyme assays. Protein concentration in the extracts was determined according to Bradford, ${ }^{45}$ using a BioRad assay kit with bovine serum albumin as standard.

Glutathione reductase (EC 1.6.4.2) was measured according to Foyer and Halliwell. ${ }^{46}$ The assay medium contained $0.025 \mathrm{mM}$ phosphate buffer $\mathrm{pH} 7.8,0.5 \mathrm{mM}$ GSSG, $0.12 \mathrm{mM}$ NADPH-Na ${ }_{4}$ and $50 \mu \mathrm{L}$ of protein extract. NADPH oxidation was determined by recording the decrease of absorbance at $340 \mathrm{~nm}$. The activity of this enzyme was expressed as $\mathrm{mU} \mathrm{mg}^{-1}$, using extinction co-efficient of NADPH $(E)=6.2 \mathrm{mM}^{-1} \mathrm{~cm}^{-1}$. One unit of GR activity has been defined as one $\mu \mathrm{M}$ of NADPH per minute under standard conditions.

Glutathione peroxidase (EC 1.11.1.9) was assayed according to the procedure of Rotruck et al. ${ }^{47}$ with some modifications. The reaction mixture consisting of $0.4 \mathrm{~mL}$ of $0.4 \mathrm{M}$ sodium phosphate buffer (pH 7.0), $0.1 \mathrm{~mL}$ of $10 \mathrm{mM}$ sodium azide, 0.2 $\mathrm{mL}$ of $4 \mathrm{mM}$ reduced glutathione, $0.1 \mathrm{~mL}$ of $2.5 \mathrm{mM} \mathrm{H}_{2} \mathrm{O}_{2}, 0.2$ $\mathrm{mL}$ of water and $0.5 \mathrm{~mL}$ of enzyme was incubated at $0,30,60,90$ seconds respectively. The reaction was terminated with $0.5 \mathrm{~mL}$ of $10 \% \mathrm{TCA}$ and after centrifugation, $2 \mathrm{~mL}$ of the supernatant was added to $3 \mathrm{~mL}$ of phosphate buffer and $1 \mathrm{~mL}$ of DTNB reagent $(0.04 \%$ DTNB in $1 \%$ sodium citrate). The color developed was read at $412 \mathrm{~nm}$ and the enzyme activity is expressed in terms of $\mu \mathrm{g}$ of glutathione utilized per min per $\mathrm{mg}$ protein.
Superoxide dismutase (EC 1.15.1.1) activity was measured according to Beuchamp and Fridovich. ${ }^{48}$ Protein extract $(50 \mu \mathrm{L})$ was added to the reaction mixture $(1.5 \mathrm{~mL})$ containing $50 \mathrm{mM}$ potassium phosphate buffer ( $\mathrm{pH}$ 7.0), $0.1 \mathrm{mM}$ EDTA, $13 \mathrm{mM}$ methionine, $2 \mu \mathrm{M}$ riboflavin and $75 \mu \mathrm{M}$ nitro blue tetrazolium (NBT). Riboflavin was added last and the tubes were shaken. The reaction was started by exposing the mixture to a cool white fluorescent light. After 15 min the light was switched off, the tubes were mixed and the absorbance measured at $560 \mathrm{~nm}$. One unit of enzyme activity was measured as the amount of SOD capable of inhibiting $50 \%$ of nitrite formation under the assay conditions.

\subsection{Statistical evaluations}

The results of DPPH scavenging activity are expressed as mean of three experiments \pm standard deviation (SD). The $\mathrm{IC}_{50}$ was calculated using OriginPro8 statistical software. The results were statistically analyzed by one way analysis of variance (ANOVA) using the SPSS statistical software package (version13.0). Comparison between $\mathrm{IC}_{50}$ values was performed with T3 Dunnett test or with Bonferroni test. The results were considered to be statistically significant at $p<0.05$.

\section{Acknowledgements}

The authors are grateful to the Ministry of Education, Science and Technological Development of the Republic of Serbia for financial support (Projects 172016, 175011 and 173005).

\section{References}

1 A. M. Pisoschi and A. Pop, Eur. J. Med. Chem., 2015, 97, 5574.

2 M. Eberlein, K. A. Scheibner, K. E. Black and W. Willet, Science, 1994, 264, 532-537.

3 R. Roberta, G. M. Luciana, C. C. Luciana and P. Glaucia, J. Food Sci., 2006, 71, C102-C107.

4 B. Halliwell and J. M. Gutteridge, Free Radicals in Biology and Medicine, Oxford University Press, Midsomer Norton, Avon, England, 3rd edn, 1999.

5 C. Siquet, F. Pavia-Martins, J. L. Lima, S. Reis and F. Borges, Free Radical Res., 2006, 40, 433-442.

6 N. Ivanović, L. Jovanović, Z. Marković, V. Marković, M. D. Joksović, D. Milenković, P. T. Djurdjević, A. Ćirić and L. Joksović, ChemistrySelect, 2016, 1, 3870-3878.

7 X. Ma, H. Li, J. Dong and W. Qian, Food Chem., 2011, 126, 698-704.

8 P. C. Eklund, O. K. Långvik, J. P. Wärnå, T. O. Salmi, S. M. Willför and R. E. Sjöholm, Org. Biomol. Chem., 2005, 3, 3336-3347.

9 C. Soares de Oliveira, B. Freitas Lira, J. M. Barbosa-Filho, J. G. Fernandez Lorenzo and P. Filgueiras de AthaydeFilho, Molecules, 2012, 17, 10192-10231.

10 H. Khalilullah, M. J. Ahsan, M. Hedaitullah, S. Khan and B. Ahmed, Mini-Rev. Med. Chem., 2012, 12, 789-801. 
11 P. Neeraja, S. Srinivas, K. Mukkanti, P. K. Dubey and S. Pal, Bioorg. Med. Chem. Lett., 2016, 26, 5212-5217.

12 A. Lukin, R. Karapetian, Y. Ivanenkov and M. Krasavin, Lett. Drug Des. Discovery, 2016, 13, 198-204.

13 M. Swapna, C. Premakumari, S. N. Reddy, A. Padmaja and V. Padmavathi, Chem. Pharm. Bull., 2013, 61, 611-617.

14 E. A. Musad, R. Mohamed, B. A. Saeed, B. S. Vishwanath and K. M. L. Rai, Bioorg. Med. Chem. Lett., 2011, 21, 3536-3540.

15 V. B. Iyer, B. M. Gurupadayya, B. Inturi, K. Venkata Sairam and G. V. Pujar, RSC Adv., 2016, 6, 24797-24807.

16 Y. Kotaiah, N. Harikrishna, K. Nagaraju and C. V. Rao, Eur. J. Med. Chem., 2012, 58, 340-345.

17 S. Bondock, S. Adel and H. A. Etman, Res. Chem. Intermed., 2016, 42, 1845-1861.

18 Dinesha, S. Viveka, S. Chandra and G. K. Nagaraja, Monatsh. Chem., 2015, 146, 207-214.

19 S. Olson, S. D. Aster, K. Brown, L. Carbin, D. W. Graham, A. Hermanowski-Vosatka, C. B. LeGrand, S. S. Mundt, M. A. Robbins, J. M. Schaeffer, L. H. Slossberg, M. J. Szymonifka, R. Thieringer, S. D. Wright and J. M. Balkovec, Bioorg. Med. Chem. Lett., 2005, 15, 4359-4362.

20 R. M. Shakir, A. Ariffin and M. A. Abdulla, Molecules, 2014, 19, 3436-3449.

21 V. Nieddu, G. Pinna, I. Marchesi, L. Sanna, B. Asproni, G. A. Pinna, L. Bagella and G. Murineddu, J. Med. Chem., 2016, 59, 10451-10469.

22 C. T. Brain, J. M. Paul, Y. Loong and P. J. Oakley, Tetrahedron Lett., 1999, 40, 3275-3278.

23 T. Isobe and T. Ishikawa, J. Org. Chem., 1999, 64, 6989-6992.

24 A. I. Vogel, in Textbook of Practical Organic Chemistry, Longman Group Ltd., London, 3rd edn, 1956, p. 782.

25 L. Wang, D.-G. Guo, Y.-Y. Wang and C.-Z. Zheng, RSC Adv., 2014, 4, 58895-58901.

26 G. Singh, S. Rani, A. Arora, D. Aulakh and M. Wriedt, New J. Chem., 2016, 40, 6200-6213.

27 R. L. Prior, X. Wu and K. Schaich, J. Agric. Food Chem., 2005, 53, 4290-4302.

28 G. Y. Liou and P. Storz, Free Radic. Res., 2010, 44, 479-496.

29 N. Hauptmann, J. Grimsby, J. C. Shih and E. Cadenas, Arch. Biochem. Biophys., 1996, 335, 295-304.
30 T. Arimoto, M. B. Kadiiska, K. Sato, J. Corbett and R. P. Mason, Am. J. Respir. Crit. Care Med., 2005, 171, 379387.

31 M. Radu, M. Munteanu, S. Petrache, A. I. Serban, D. Dinu, A. Hermenean, C. Sima and A. Dinischiotu, Acta Biochim. Pol., 2010, 57, 355-360.

32 J. Blum and I. Fridovich, Arch. Biochem. Biophys., 1985, 240, 500-508.

33 R. S. Treger, A. G. Cook, G. Rai, D. J. Maloney, A. Simeonov, A. Jadhav, C. J. Thomas, D. L. Williams, M. Cappello and J. J. Vermeire, International Journal for Parasitology: Drugs and Drug Resistance, 2012, 2, 171-177.

34 H. C. Hansen, F. S. Chiacchia, R. Patel, N. C. W. Wong, V. Khlebnikov, R. Jankowska, K. Patel and M. M. Reddy, J. Med. Chem., 2010, 45, 2018-2023.

35 M. Kidway, D. Bhatnar and N. K. Mishra, Green Chem. Lett. Rev., 2010, 3, 55-59.

36 D. Suresh, K. Kanagaraj and K. Pitchumani, Tetrahedron Lett., 2014, 55, 3678-3682.

37 Y. Kumarasamy, M. Byres, P. J. Cox, M. Jaspars, L. Nahar and S. D. Sarker, Phytother. Res., 2007, 21, 615-621.

38 O. Erel, Clin. Biochem., 2004, 37, 277-285.

39 R. J. Ruch, S. J. Cheng and J. E. Klaunig, Carcinogenesis, 1989, 10, 1003-1008.

40 V. L. Singleton and J. A. Rossi, Am. J. Enol. Vitic., 1965, 16, 144-158.

41 T. L. Pownall, C. C. Udenigwe and R. E. Aluko, J. Agric. Food Chem., 2010, 58, 4712-4718.

42 T. Mosmann, J. Immunol. Methods, 1983, 65, 55-63.

43 M. Ohno and T. Abe, J. Immunol. Methods, 1991, 145, 199203.

44 M. V. Rodić, V. M. Leovac, L. S. Jovanović, V. Spasojević, M. D. Joksović, T. Stanojković, I. Z. Matić, L. S. VojinovićJešić and V. Marković, Eur. J. Med. Chem., 2016, 115, 75-81. 45 M. M. Bradford, Anal. Biochem., 1976, 72, 248-254.

46 C. H. Foyer and B. Halliwell, Planta, 1976, 133, 21-25.

47 J. T. Rotruck, A. L. Pope, H. E. Ganther, A. B. Swanson, D. G. Hafeman and W. G. Hoekstra, Science, 1973, 179, 588-590.

48 C. O. Beuchamp and I. Fridovich, Anal. Biochem., 1971, 44, 276-287. 